\title{
FDI - have a game changing impact on the modern retail sector in India
}

\author{
Samridhi Goyal ${ }^{1}$, Prabhjot Kaur ${ }^{2}$, Kawalpreet Singh ${ }^{3}$ \\ ${ }^{I}$ Asst. Professor with Desh Bhagat College, Bardwal, Dhuri Punjab, India \\ ${ }^{2}$ Asst. Professor with S.G.G.S. Khalsa College Mahilpur, Hoshiarpur, Punjab, India \\ ${ }^{3}$ Manager (H.R and Admin) with SARLI Technologies, Amritsar, Punjab, India
}

\begin{abstract}
Modern Retail in India has seen a significant growth in the past few years. With large scale investments coming from the big Indian corporate houses such as Reliance, Bharti, etc, primarily in Food and Grocery retailing, the Indian retail industry has witnessed a renaissance. With changing consumer behavior and with the India's need of technological and infrastructural development, now the wind is blowing towards allowing 100\% FDI in multi brand retailing in India. And, if this happens, then it will have a game changing impact on the modern retail in India. FDI in Indian retail sector has opened doors for the foreign investors like Wal-Mart, etc; to invest in lucrative and still untapped Indian retail market and this is destined to change the retail landscape forever in India. Number of factors like stable economic policies, availability of cheap and quality human resources and raw material, opportunities of new unexplored markets and a number of macroeconomic factors have catch the attention of the foreign investors towards India retail sector. The research findings indicate that with FDI in Indian retail sector, middlemen will be eliminated from the supply chain; direct market accessibility to farmers will give them a better price for their produce and hence increased profits; enhanced competition will benefit consumers and the government revenues will rise too. This paper concludes with the opportunities and the latest developments in the Indian retail sector.
\end{abstract}

Keywords: FDI in Indian retail sector, Modern retail in India.

\section{Introduction}

With the Foreign Direct Investment (FDI) we in layman's language mean the investment done by the investor in an economy or in an enterprise operating in an economy other than that of his own country of residence. For example, a person named " $Z$ " who is a resident of Russia invests his money in India. His investment may be through some joint venture in India with an Indian company or by exporting technology available in his country into India or through participation in management or operations of a firm/organization operating in India that is not solely owned by him, etc. In December 2012, Indian parliament allowed the foreign direct investment in multi-brand retailing. Indian retail sector, which is typically unorganized, operates on the old traditional methods and it employs about 3.3\% of the total Indian population. The size, infrastructure and investment of the typical Indian retail shops are very small. Approximately over 14 million outlets operate in the country and there are approximately on an average about 11 shops/outlets for every 1000 people in India. The retail business in India is mostly hereditary owned with vast majority of the retail shops owned by the family members, also they are run by the family members and they employ the family members in the day to day business of the shops. These vast majority of unorganized shops operate on a limited level as they have the limited area of operations, also these do not have much of the magnitude to procure or transport products as there sales volume is limited and does not exceeds a specific level as it is confined to a day to day business policy in which the products are procured on a daily basis every morning and by the end of the evening the main motive is to sell all the perishable products. These kinds of retailers also have very less or in most of the cases no quality control. Due to lack of space, investment and modern technology these small retailers have the problem of safe and hygienic storage of the products or the packaging and transportation of the products from one place to another. Sometimes (in case of less sales) all or most of the products due to their perishable nature gets rotten or damaged which transporting and this again acts as a burden on the shopkeeper/the retailer as it is a direct loss of money and in this case the investment made by the small retailer. These unorganized retailers procure their products on a daily basis from the middle man who earns his profits as the product moves from the farmers or the producers to the consumers. This profit earning by the middle men raise the price of the product as it moves forward on the supply chain. The more people get involved into the supply of the product from the producer of the product to the consumer or end user of the product the more the price of the product rises. Also, these unorganized retailers/retail shops do not offer the after sales services or support to the consumer. Nearly all the transactions are in the form of cash and are final with nearly zero percentage of credit or after sales support offered to the consumers. Until the year 1990, the Indian government through its legal compliances such as signboard licenses, anti hoarding measures (to name a few); prevented innovation and entrepreneurship in 
retail sector of India. Taxes were imposed on the transportation of goods from one state to another. Middlemen monopolies have always overpowered the farmers and the producers. Until 1990 the state of logistics in India was very poor. The owners had to bear in the loss exceeding $30 \%$ while transporting goods from one place to another. But all this is a thing of past today. After 1990, India introduced a series of storms of reforms and advancements in the retail sector. Also, today's consumer has awakened and is more concerned about the quality of the products they are procuring. The consumer has option available with him today. They are more concerned with their convenience, they look for the shops or outlets which are into their reach and are happier to shop under one roof instead of roaming from street to street. They are more in favor of organized retail industry than they ever were. They are awake and now want to reap the benefits of the organized retail industry which offer them options to choose from and which are available at their convenience and comes along with the assurance of quality. This has all been possible because of the Liberalization, Privatization and Globalization (LPG model) introduced in India since 1990. This LPG model has positively and very heavily affected the Indian retail sector and since its introduction the Indian retail industry is growing rapidly. With the change in income level of the consumer, their taste and habits have changed strongly, their preferences and lifestyle have changed, the consumer now wants the superior quality and branded products. With the change in consumer behavior the Indian market has now turned into a very competitive manufacturing base. This positively changing Indian consumer behavior and changing trends in Indian retail sector have attracted the attention of the multinational companies and they are starving to enter the big pool of profit making that exists in the Indian market. Indian retail sector is drawing attention of the foreign investors as the area of retail is unexplored and has huge profit making potential. This attention of foreign investors is vital for developing Indian economy on the whole and specifically the Indian retail sector. This will bring the new advanced global technology which will make Indian retail sector stand shoulder to shoulder with the global retail market. It will also give the Indian consumers the best quality products under one roof. The investment from foreign players will boost the business, employment, trade, demand, consumption, supply and hence income of the retailers. Earlier studies show that the retail sector in India is marking a compound annual growth rate (CAGR) of 5.9 per cent since 1998. The total market size of the Indian retail sector is expected to reach US\$ 574 billion by 2015 that will have a game changing impact on Indian economy. Backed by the words of Prime minister of India, Dr. Manmohan Singh "We need greater competition and therefore, need to take a firm view on opening up of the retail trade" the government has also taken a number of active steps to encourage the growth of the Indian retail industry. India has modified its policies to boost the money inflow from foreign players in the Indian economy especially in the Indian retail sector. The foreign direct investment in the Indian retail industry is encouraging the growth and strength of the retail business and this is also helping in creating the ever required infrastructure and global manufacturing competencies and strength to the Indian production network, marketing, storage and distribution system. Investment from the foreign players is proving a boon required for the overall growth of the Indian economy. Government has opened the gates for the foreign investors to invest their valuable money in the lucrative Indian retail sector and these measures of the Indian government are directed towards changing the face of the Indian retail sector giving it a globally competent look. The Government of India has approved 51 per cent foreign direct investment (FDI) in multi-brand retail and increased FDI limit to 100 per cent in single brand retail and for cash and carry (wholesale) trading and exports. The foreign direct investment in retail will help consumers and producers to come in direct contact with each other. The growing urbanization in India and changing consumer behavior is further pointing towards the scope of expansion for retail sector. Moreover Indian rural market still remains untapped which have far more growth potential that is again untapped and is lying unorganized. Efforts are being made to organize the retail sector and according to a research the organized retail segment in India is expected to be 9 per cent of total retail market by 2015 and 20 per cent by 2020 . The foreign direct investment will help in organizing the Indian retail sector and it will further improve the supply chain in the retail segment. An improvement in supply chain will have far reaching implications for farming sector. Farmers produce goods and take them to open market where the middlemen between the supply chain reaps the profit that in real sense belong to the farmers. Farmers or producers do this because of their convenience and also due to their lack of ability to tap the various potential markets on their own. The foreign direct investment in the Indian retail sector will help develop the strength of Indian retail and it will eliminate the middlemen from the supply chain and the farmers will be able to sell their produce directly to the retailers and hence consumers and this will help the farmers reap the profits from the supply chain in the absence of the middlemen. The farmers would be able to access the new markets on their own as the big stores would be available to them at their convenience where they could sell their produce at very good rates. This would also bring the fresh quality products in the reach of the consumers. With the government giving a nod for $51 \%$ FDI in multi-brand retail sector and 100\% FDI in single brand retail, the question which has come up is that whether this development in the Indian retail industry or in simple allowing the foreign direct investment in the Indian retail industry would prove to be a boon or a bane for the Indian retail sector? Different surveys are extensively being conducted in the open market to know the views of the people and especially of the retailers. These 
surveys show that where on one side the most retailers operating in the multi-brand retail space are happy about the decision of the government to allow the $51 \%$ foreign direct investment in multi-brand retail sector and $100 \%$ foreign direct investment in the single brand retail, but on the other side the small retailers are anxious.

\section{Rationale of the study}

With increasing globalization and dynamic trends, India too needs to develop its infrastructure to match the rising demands and the living standard of its citizens. In order to match and compete in the global competition, India needs investment from sources other than its domestic sources. So, the interest is towards bringing the foreign money into India so that the Indian state and its citizens can become technologically and infrastructurally developed and competent to its core. With changing life style and attitude of the Indian consumer it has become extremely important to develop the Indian retail sector. For this reason, government is consistently making efforts to allow Foreign Direct Investment (FDI) in multi brand retailing in India. FDI in Indian retail sector will bring with it its positive and negative impacts. But to get something we have to let something go; if the gains are on a higher side. This study focuses on highlighting the merits and demerits of the FDI with its impact on overall Indian economy and its development. The main aim behind the study is to put forward the game changing impact of the FDI on the modern retail sector in India.

\section{Objectives of the study}

1) To highlight the impact of FDI on the modern retail sector in India.

2) To identify the impact of FDI on the overall development of Indian economy and its infrastructure.

Research Type: Descriptive Research

- Type of Data/Data Source used: Secondary Data/Data source. The present study is based on secondary data. Basically, the required information has been derived from

- Various books.

- Articles from Newspapers, Magazines and Journals, and

- From the various related web-sites which deal directly or indirectly with the topics related to FDI and Indian retail sector. After searching the important web-sites, relevant information was down loaded and analyzed to address the objectives of present study.

\section{Limitations of the study}

1. The study is based on published data and information. No primary data is being collected.

2. Every care has been taken to entice qualitative and correct data; still secondary data have collected for the purposes other than problem at hand.

3. The objectives, nature and methods used to collect secondary data may not be appropriate to the present situation.

4. Secondary data may be lacking in accuracy, or they may not be completely current or dependable.

5. Time constraint remained the major limitation in the study

6. The biasness can always be there.

7. Before using secondary data, it is important to evaluate them on above mentioned factors. So, it consumes the same time as the primary data.

\section{Employment:}

\section{Impact of FDI on Modern Indian Retail Sector}

The industry experts foresee a very positive scenario on the employment grounds. According to Rituparna Chakraborty, Vice- President, Indian Staffing Federation, "It is estimated that FDI in retail can create approximately 4 million direct jobs and almost 5 to 6 million indirect jobs including contractual employment within a span of 10 years, making it the largest sector in organized employment." The government of India has also backed these kinds of statements by saying the allowing the FDI in retail sector will help create 10 million new jobs for the people of India. Experts also predicts that allowing the FDI in retail sector will increase the job opportunities across all levels and profiles and the demand for skill, unskilled and semi skilled workers will rise around all the spheres across all the profiles and levels. As clear from the statements by the industry experts such as Seema Arora Nambiar, Senior Director, People Resources, McDonald's India (West \& South Region) it is clear that the FDI in retail would bring a storm of employment opportunities for the people. According to her, "With the opening up of the Indian market to single-brand FDI employment opportunities, especially, at the entry level, will rise. Profiles such as sales, supply chain executives, security personnel, attendants, in-shop supervisors, floor managers and warehouse supervisors are likely to see significant increase in demand." Seema Arora is not the only one who thinks that the FDI will pump the 
employment in the retail sector, but there are many more who have the same viewpoint as of hers. Dr Virendra P Singh, Executive Director- Human Resources \& Chief Pupil, RJ Corp/ Devyani International Limited/ Devyani Food Street Limited has assured that FDI in retail will without any doubt have a positive impact on employment trends in the Indian retail sector by saying, "The revitalized retail industry will require a larger work force with better skill sets to produce and service an ever increasing customer base from big cities to small towns, and subsequently tehsils and village markets and this will usher a skill revolution in the industry." Several other studies on the FDI shows that because of the investment by foreign companies in Indian economy especially in retail sector, job opportunities in areas like marketing, customer care, agro-processing, quality control, packaging, transportation, etc. will be created. With opening of the new markets and retail segment getting organized, new job opportunities will arise for the Indian youth into the fields of customer service and store management. Besides generating the employment opportunities, the growing global competition will also develop the skill sets of the Indian employees.

\section{Supply chain:}

Besides raising the employment opportunity level, the investment from the foreign players or the big entrepreneurs in Indian retail, it will change the overall fate of the Indian retail industry. The structure of the supply chain will change; which will bring cheer on the faces of both the consumers and the producers. Because of the FDI, the middlemen in the supply chain will disappear from the supply chain. Because of that, farmers will get a good price for their produce and when they will get the deserved price for their products; their exploitation will stop (which is going on from the last 150 years). Farmers will tap new export opportunities besides getting rid of their exploitation done at the hands of the commission agents or the middle man who absorb the major share of profits actually meant for the farmers or the producers of the commodities.

\section{Infrastructure:}

Foreign companies will bring with them the investment of around $\$ 100$ million in India. Because of that, overall infrastructure facilities, refrigeration and storage technology which help food from getting waste, transportation, quality of products, after sales support and services facilities, producer-consumer relationship, etc. will be renovated. Global competition and enhanced consumer taste will also force the Indian manufacturers to produce a very fine quality of goods. Ultimately the Indian consumer will get the benefits of the competition with the best quality products and the choice between the products available to them in the market. The benefits of allowing the FDI in retail can have a tremendous positive impact on the health of a country, and this can be proved with the example of foreign countries like China, Indonesia, and Thailand who have experienced tremendous positive growth on the technological sphere, manufacturing sphere, consumer-producer relationship, and their infrastructure has also strengthen by allowing 100\% FDI in their retail sector. Foreign companies will ensure the decline in the wastage of the food/perishable products. They will also create an organized supplychain in the Indian market; and because of the better storage and transportation facilities, better infrastructure and refrigeration facilities the nutritional value and good quality health of the food/product will remain intact and hence this will automatically lower the rate of the food wastage. India needs to develop its overall infrastructure along with the current state of its retail industry, which is unorganized but have a very high growth potential. India needs housing, hospitals, schools, developed roads and technology to match its growing population and its needs. All of this needs money and the government of India's this move of allowing FDI in single and multi brand retail will bring in the flood of money inflow into India by the foreign retail giants. As per the legal condition laid down by the government of India for the foreign investors who want to invest in retail industry in India, these foreign investors have to procure 30\% of their products from the domestic Indian manufacturers. This is help in developing the quality of the end products and also foreign investors will bring with them the internationally reckoned technology to Indian market. More money in hand will develop the transportation, storage of the products which will reduce the wastage of the products and tap the growing prices of the goods. This will further control the growing inflation in the Indian market. With money in hand, India can invest in research and development, besides developing its infrastructure. Hence with the money in hand, India will not only develop its existing retail segment but it will develop India strategically, technologically to its core in every manner and field.

\section{Quality of goods:}

With globally recognized technology and retail giants coming to India, the domestic manufacturers will have to produce extra fine quality of goods for the consumers. The internationally challenged quality will be demanded by the consumers who ask for the value of money. 


\section{Competition:}

According to a stipulation laid down by the Indian government over the foreign retailers who wish to enter in the Indian market; these foreign retailers will have to procure $30 \%$ of their goods from the domestic Indian consumers. This will add up to the competition between the Indian manufacturers and they will leave no stone unturned to survive in such a competitive environment. They will have to prove themselves to the customer expectations in terms of quality of the goods manufactured, price of the goods and the availability and variety of the goods manufactured by them. They will have to meet very rapidly with the changing consumer behavior and hence all of this will lead to a neck to neck competition among the domestic Indian manufacturers.

\section{Inflation:}

According the industry experts the inflow of foreign money into India will control the rising level of inflation. Rise in the prices of products is basically because of the shortage of money and when the money will flow in abundance in India, it will defiantly result in controlling the inflation. Hence people will not have to worry about the rising prices of the commodities when they will have the options to choose from.

\section{Current and future state of Foreign Direct Investment (FDI) in Indian retail sector}

Indian retail sector has been the backbone of the Indian economy since ancient times. According to the data concluded from the previous studies, retail industry of India accounts to 14 to 15 percent of its GDP and besides this it is one of the top ten retail markets of the world, estimated to be around US \$ 500 billion in size. Till 2011 the Indian retail sector was unorganized and managed by small shops, with only a few big retail shops are present in its urban sector. Government of India too kept opposing the foreign players in the Indian retail industry banning their direct ownership in the Indian retail especially in multi brand retailing. Even in single brand retailing the participation of foreign players was limited to 51\%. After the year 2012, the Indian government has introduced a series of reforms in both the single and multi brand retailing allowing $100 \%$ ownership of foreign players in the retail sector in both single and multi brand retailing, but besides this the government of India has imposed a restriction to procure 30\% of their products from the Indian domestic manufacturers. These reforms have allowed the big foreign players such as Wal-Mart, Carrefour, Tesco to place their feet in the Indian retail market. The 51\% FDI in the multi brand retailing by the foreign players also comes with a limitation imposed with it. Individual states have the right to allow or ban the foreign players in their respective states. With this the renaissance in the Indian retail has taken place. The face and body of the Indian retail industry will be affected and changed with these reforms and the FDI in the modern Indian retail sector will have a game changing impact on the modern Indian retail sector. Allowing FDI in the Indian retail sector will help India live up to its dream and vision. Foreign investment in Indian retail will bring foreign money in India and with this money India could develop its infrastructure and could match with the ever growing and changing life style of its citizens. These new reforms will create new jobs in India (as predicted by the industry experts). It will also permit the E-Business in India which is a trend now a days with Indian citizens.

\section{Controversies tagged with the FDI in Indian retail sector}

Nothing is free of criticism in this world. And hence the Indian Governments' decision of allowing 100 $\%$ FDI in single brand retailing and 51 \% FDI in multi brand retailing is also not free from the criticism. The critics of the decision are worried about the position of the middle man in the Indian retail. Now, all the produce of the Indian farmer or the manufacturer is sold in the open market through a proper retail channel which involves a middle man who procures the produce from the producer and sells it to the Indian retailer at wholesale price which further is sold by the retailer in the open market. The critics are worried about the elimination of the middle man from the supply chain as FDI would allow the retailers to have such a developed infrastructure and a proper place where the producer or the manufacturer could sell their product directly to the retailer. The critics have forgot the benefit that this elimination of the middle man would bring to the producers or manufacturers and ultimately to the consumers. When the producer will sell its produce directly to the retailer, he would get proper price for his produce and hence more profits on the produce, which earlier the middle man used to take. Middle man procure the produce on low price and add his own profits to the price of the goods and sell it to the retailer who in turn again raise the price of the product by adding his own profit in it. This movement of the goods through the middle man to the retailer and finally to the consumer raises the price of the product and ultimately the consumer has to suffer by paying extra bucks from his pocket. Elimination of the middle man would help the producer sell its produce directly to the retailer who will sell the product further to the consumer on a low price because now the profits earlier reaped by the consumer is divided among the producer and the consumer. Hence all are happy; producer who gets good price for his product and without any doubt the consumer who will have to pay less from his pocket. Except this middle man problem, critics also say that the FDI will result in the loss in jobs in India. They have over looked the fact that instead of resulting in job 
loss, the FDI will create new jobs. Currently, Indian retail sector is unorganized and is mainly managed only by the family members. Who employ one or two or sometimes no one on their retail shops. They are overlooking the fact that instead of losing the jobs, the FDI in Indian retail would create more jobs as on big retail shops the retailers would need the customer care executives, channel managers, etc. So, instead of resulting in the job loss, the reforms in the Indian retail would create many more job opportunities. Moreover the current Indian retail sector employs the employees with no fixed hours of work and proper salary and salary structure. The FDI in the Indian retail will develop the Indian retail sector which will provide proper remuneration to its employees with the $100 \%$ chances of salary hike which is essential for the growth and development of the employee and his family over the time. Another point that draws the attention of the critics is that the FDI in Indian retail would allow the foreign giants to procure the $70 \%$ of their material from the international market. They again have overlooked the fact that these foreign retailers will have to procure their $30 \%$ material from the Indian domestic producers, which will enhance the quality, price and production of the Indian goods. They goods produced by the Indian manufacturers will be of the international quality which will be globally competent and also the Indian domestic industry would flourish with it. The critics of the FDI also say that India does not need the foreign players in the Indian retail sector as already the job is well done by the domestic players. But they have forget that we are now living in the $22^{\text {nd }}$ century and our needs, our life style and our behavior has and is continuously changing with time and globalization. The living style of the Indian citizens have witnessed a drastic change over the time and now Indian consumer wants everything at his convenience and at arm's length under one roof, without having to move from street to street for getting something for their daily life. Also the quality of the goods as desired by the Indian consumer is very high. And quality of the products could only be improved through competition.

\section{Reaction of various political parties, Economists, Entrepreneurs and Farmer groups} towards FDI

Many people have many responses towards the Indian government's decision of allowing FDI in Indian retail industry. With farmer groups, economists and entrepreneurs supporting the Indian government's this move, many political parties and the cultural groups are against the government's decision. Farmer groups like All India Vegetable Growers Association (AIVGA), Bharat Kisan Samaj, Consortium of Indian Farmers Association (CIFA), etc have supported the Indian government's move of allowing FDI in Indian retail sector. Organized retail would allow Indian farmers more competent markets to sell their produce at better price. Currently, Indian farmers gets one-third of the total price that the Indian consumer pays for their products, but with the organized retail sector, farmers would get better and deserved price for their products which is currently absorbed by the commission agents or the middle man, and hence happy farmer and happy consumer. So, in simple words, FDI will eliminate not only the middle man but also the exploitation that is offered by the middle man to the farmers. Economists and the Entrepreneurs have also welcomed this FDI in Indian retail sector as it would bring the much needed investment in the Indian infrastructure, refrigeration, storage, warehousing and contractual farming. At the time when allowing reforms like FDI in the Indian retail has bring smiles on many faces and many farmers' associations and the entrepreneurs and economists have backed the government's decision, there is a very strong opposition to the move in the political arena. Opposition in the wake of their protest launched a nationwide band on December 2, 2011. Indian parliament remained suspended over the issue for the entire week of November 28, 2011. States like Delhi, Kolkata, and Tamil Naidu have opposed the FDI in multi brand retail and their respective governments have also claimed that they would not allow any big retail stores in their states.

\section{Conclusion}

Foreign Direct Investment is the need of the hour if India needs to develop its economy, infrastructure, etc. Amid chaos, political controversies and debate, the government of India has passed the 100\% FDI in single brand and 51\% in multi brand retail. Negative or positive, the FDI in Indian retail sector without any doubt will have a game changing impact on modern retail in India. FDI will bring new opportunities for the farmers and manufacturers who will get rid of the exploitation suffered at the hands of the middle men or the commission agents and will get the much deserved and better price for their produce. New job opportunities will crop up for the Indian youth. Better storage and refrigeration facilities will cut down the wastage of the products. Consumer will get best quality products amid severe competition. Domestic manufacturers will get updated globally reckon technology which will benefit both the manufacturers and the consumers. Foreign investment in India will bring strength to the Indian economy. Investment can be made in developing the infrastructure. This research paper is directed towards analyzing the game changing impact of FDI on the modern retail in India. Political parties or the people who are opposing the FDI in Indian retail sector will realize in future that they have been opposing the path of development of not only India but their personal development too. Foreign investment will bring with it happiness; happiness on the face of the manufacturer or the producer and on the 
consumers. After reviewing the secondary data available we through this paper can rightly conclude that FDI will have a game changing impact on the modern retail in India and the benefits of this move by the government of India will be reaped by the Indian consumer whose life style, needs and buying behavior is rapidly changing with time and growing global interaction. At present Indian retail sector stand among the top five retail markets in the world. So, the benefit of allowing FDI in modern Indian retail cannot be under estimated if India needs to keep pace with the global players. Countries like China, Thailand, and Singapore are the proof of the benefits that the FDI will bring with it. These countries have witnessed the growth, development and positive changes that FDI has brought along it. With the investment from the foreign players, India could invest in building hospitals, in developing the roads, in setting up new research schools, in building housing for its growing population, etc. Untapped potential markets will get explored; unorganized retail sector will get organized, new export markets will also open up for the Indian farmers. With higher disposable income at the hands of the Indian consumers, rapid urbanization, and growing needs of India, the FDI will come as a boon for India. FDI will change the existing face of the Indian retail industry and not only the retail sector but overall Indian economy will get benefited from the FDI. Corruption will be tamed, technological competencies will be attained throughout India in every field and all of this will be focused on the high well being of both the consumers and the producers - the citizens of India. So, it can be right fully concluded from this research paper that FDI will have a game changing impact on the modern Indian retail sector and not only retail sector but whole of India would reap the benefits of this decision of the government.

\section{Acknowledgement}

Our endeavor shall be incomplete without the acknowledgement to all those personalities who have extended full co-operation and valuable assistance to us in making this research paper a reality. We would thus, like to take this opportunity to convey our deepest feelings of gratitude to all for giving this research paper the final and desired shape. Our families, some untold friends and our teachers have always been a support and source of great inspiration.

\section{Journals/ Articles}

\section{References}

[1] M. Patibandla, (2012). Foreign Direct Investment in India's Retail Sector: Some Issues, Working Paper No. 366, Indian Institute of Management Bangalore.

[2] R. Bhattacharyya, (2012). The Opportunities and Challenges of FDI in Retail in India, IOSR Journal of Humanities and Social Science, 5(5), pp. $99-109$

[3] Dr. Manish Khare, Foreign Direct Investment in Indian Retail Sector - A SWOT Analysis. AISECT University Journal Vol. II/Issue IV Sep. 2013. ISSN: 2278-4187.

[4] K. R. Kaushik, \& Dr.Kapil Kumar Bansal, Foreign Direct Investment in Indian Retail Sector Pros and Cons, International Journal of Emerging Research in Management \& Technology, Research Article 2012. ISSN: 2278-9359.

[5] Dr. G. Shashidhar Rao, \& Ch. Prashanth. Foreign Direct Investment in Indian Retail. Industry. International Journal of Commerce, Business and Management. Vol. 1, No.1, 2012.

\section{Websites}

[6] http://www.spaceandculture.in/index.php/spaceandculture/article/view/17/7

[7] http://www.ibef.org/industry/retail-india.aspx

[8] http://en.wikipedia.org/wiki/Retailing_in_India

[9] http://en.wikipedia.org/wiki/Retailing_in_India\#Controversy_over_allowing_Foreign_retailers

[10] http://www.fibre2fashion.com/industry-article/free-retail-industry-article/indian-retail-industry-itsopportunities/indian-retail-industry-its-growth-challenges-and-opportunities1.asp

[11] http://www.fibre2fashion.com/industry-article/free-retail-industry-article/indian-retail-industry-itsopportunities/indian-retail-industry-its-growth-challenges-and-opportunities 1.asp opportunities/indian-retail-industry-its-growth-challenges-and
http://info.shine.com/Industry-Information/Retail/139.aspx

[13] http://retailindustry.about.com/ 